\title{
STUDY OF THE ZOOPLANKTON COMMUNITY AS AN INDICATOR OF THE TROPHIC STATUS OF RESERVOIRS
}

\author{
*Irina V Mashkova ${ }^{1}$, Anastasiya Kostriykova ${ }^{1}$, Elena Shchelkanova² ${ }^{2}$ Viktor Trofimenko ${ }^{3}$ and Alina \\ Slavnaya ${ }^{1}$ \\ ${ }^{1}$ Institute of Natural Sciences and Mathematics, South Ural State University, Russia; ${ }^{2}$ Institute of \\ Linguistics and International Communications, South Ural State University, Russia; ${ }^{3}$ South Ural State \\ Humanitarian Pedagogical University, Chelyabinsk, Russia
}

*Corresponding Author, Received: 19 Dec. 2019, Revised: 20 Jan. 2020, Accepted: 20 Feb. 2020

\begin{abstract}
Over the past thirty years human activity has become increasingly uncontrolled. As a result, the whole water ecosystem is transforming. Unlike natural water bodies, artificial water bodies are characterized by higher rates of eutrophication. The current paper defines the chorological structure and biomass of zooplankton communities in the reservoirs of the Chelyabinsk region. It reveals the influence of the ecological continuum on the formation of the chorological structure of zooplankton in artificial reservoirs. The given research shows that the total biomass of the representatives of the studied groups of zooplankton in eutrophic reservoirs is two times less than in mesotrophic. These are the signs that indicate biocenoses degradation. An increasing anthropogenic load has changed the chorological structure of zooplankton communities in water bodies. The obtained results show that the proportion of Cladocera in mesotrophic reservoirs is higher than in eutrophic. The Rotifera group is more common in eutrophic reservoirs than in mesotrophic ones. Copepods are common to all water bodies. Six taxons out of the predominant are registered as belonging to the dominant complex (D. cucullata, D. pulex, D. longispinae, Eudiaptomus graciloides, Thermocyclops oithonoides, Cyclops vicinus). D. cucullata is the only that is registered as a part of the dominant complex in the vast majority of study periods and spreads as a dominant in five reservoirs.
\end{abstract}

Keywords: Zooplankton, Eutrophic Reservoirs, Mesotrophic Reservoirs, Biocenoses Degradation

\section{INTRODUCTION}

Human activity has become less controlled recently. It brings to the ecological destructive effects connected with decreasing ecosystem stability [1]. As a result, water ecosystems have been transformed for the last thirty years, which can be compared with natural changes embracing entire geological eras [2]. Trophic status is one of the distinctive features of water ecosystems. Unlike natural ecosystems, artificial reservoirs are distinguished by increasing eutrophication. Thus, such water bodies must be researched to identify anthropogenic changes against the background of natural ones [3].

In the framework of water bodies' environmental research, zooplankton has been more frequently biomonitor [4]. The relation of water bodies trophic status with zooplankton quantitative and qualitative characteristics has been often studied regionally [8-14]. Zooplankton communities are completely or partially replaced $[17,18]$ due to the water bodies' environmental changes [15]. Studies 1,2,7,8 show how indicator species can be used to assess water quality. They consider the complex nature of hydrobiots' interrelation under adverse environment for the analysis of water ecosystem status. In spite of the bioindication methods for the assessment of the water bodies trophic status being internationally acknowledged [19-22], the approaches to this research are controversial [9-11, 23].

In the Chelyabinsk region, 6 of 377 water reservoirs are actively exploited. They are of different sizes, water regimes, salinity, etc. [24]. However, the ecological continuum of zooplankton species in artificial reservoirs in the Chelyabinsk region is scarcely studied. There are few works on spatial distribution and seasonal changes in population and biomass [25].

The current paper aims at identifying the chorological structure and biomass of the zooplankton community in the reservoirs of the Chelyabinsk region (Russia) and the impact of the ecological continuum on the structure's formation in artificial reservoirs. Studying the chorological structure of the zooplankton community will allow identifying indicator species that can be used to determine water pollution.

\section{METHODS}

\subsection{Study Area}

In the Chelyabinsk region there are now 377 [24] water reservoirs of different sizes, water 
regime, salinity, etc. [26]. Such water bodies being very specific differ significantly from natural. Water is accumulated due to the rivers forming them, snowmelt runoff in spring and residual rainfall. In summer salinity and $\mathrm{pH}$ levels differ with weather conditions and other reasons. salinity can fluctuate up to $50 \%$ within a season [7].
The current research covered 6 artificial reservoirs in the Chelyabinsk region (Russia):

Argazinskoye, Verkhne-Iremelskoye,

Verkhneuralskoye,Dolgobrodskoye,Shershnevskoy e and Yuzhnouralskoye (Fig. 1). These reservoirs are under different degrees of anthropogenic impact, which is seen in their different trophic status.

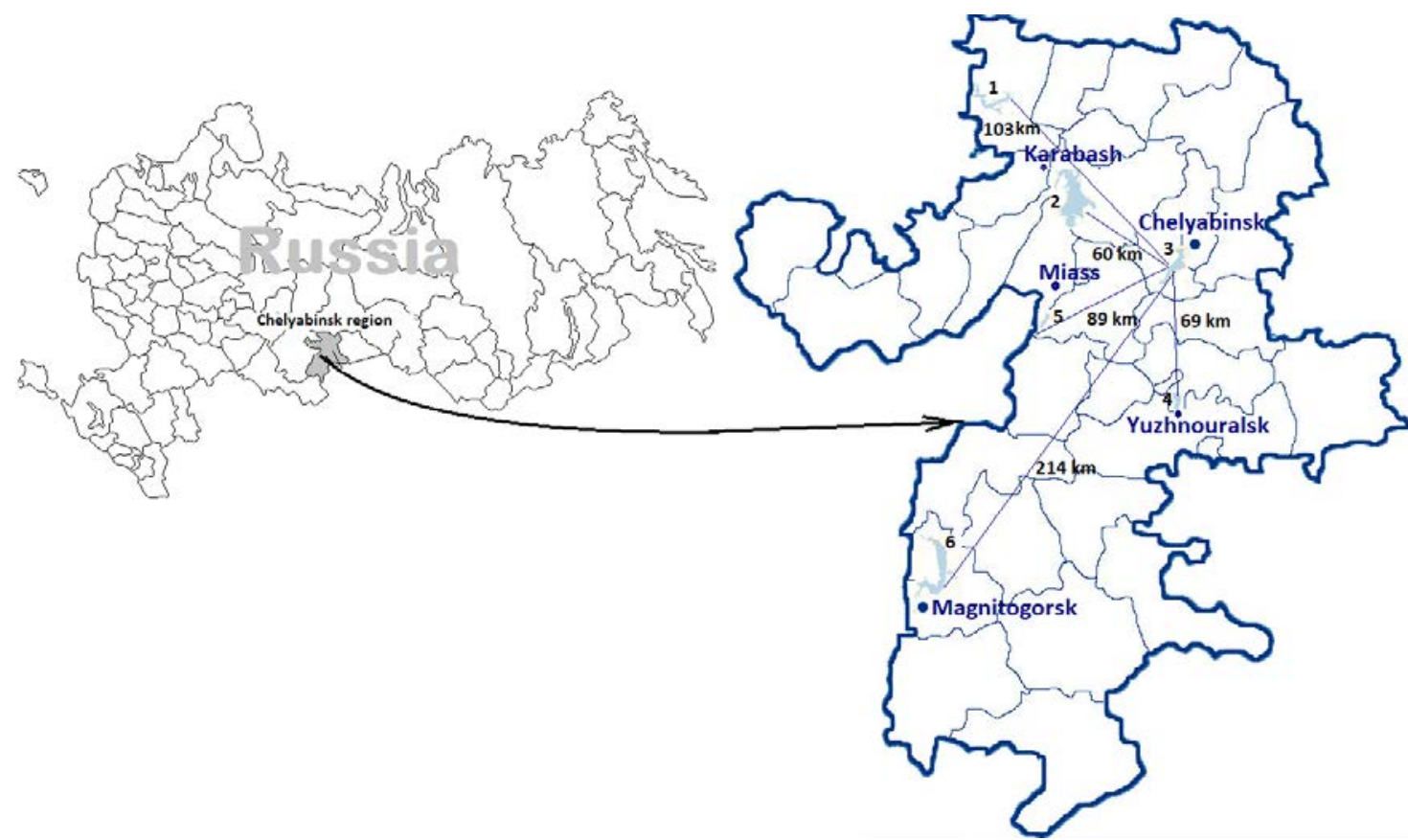

Fig.1 Reservoirs location and relative distance from the city of Chelyabinsk: 1 - Dolgobrodskoye, 2 - Argazinskoye, 3 - Shershnevskoye, 4 - Yuzhnouralskoye, 5 - Verkhne-Iremelskoye, 6 - Verkhneuralskoy

\subsection{Sample Collection}

The primary data was collected in the following order. In June and July 2016 samples were taken in the Verkhneuralskoye reservoir (3 sites), Yuzhnouralskoye reservoir (3 sites) and Shershnevskoye reservoir (5 sites). Samples in Argazinskoye (4 sites), Verkhne-Iremelskoye (3 sites) and Dolgobrodskoye (2 sites) were collected in June and July 2017. Inventory and taxonomic classification of species were done in 2018 [27-35].

Conical plankton net was used for catching zooplankton (upper ring diameter is $18 \mathrm{~cm}$; bottom ring diameter is $24 \mathrm{~cm}$; cell size is 25 micron). Samples of water with zooplankton were filtered with $30 \mathrm{l}$ of surface water through the net [36-38]. Then, the samples were fixed with $5 \%$ formalin and made up to $100 \mathrm{ml}$. 3 successive samples $1 \mathrm{ml}$ each were examined with the binocular microscope Altami BIO 2T (Altami Ltd, Russia, St Petersburg). The average amount was analyzed, and the results were shown as animal biomass in $\mathrm{Mg} / \mathrm{M}^{3}$. Zooplankton biomass was estimated with the standard counting method [39, 40]. Zooplankton taxons were identified with the published papers [27-35].

\section{Results and Discussion}

The studied reservoirs are characterized by different trophic status [41]. They are under different anthropogenic impacts. The biomass of 32 zooplankton species was determined. All the registered species belong to Crustacea class (11 species of Cladocera and 7 species of Copepoda) and Rotifera class (14 species). Table 1 gives species composition, biomass, each species confinement to the studied reservoirs.

As the table shows, the species composition in different reservoirs does not differ significantly and ranges from 23 to 30 . The largest amount of species (30) was found in mesotrophic and oligotrophic Dolgobrodskoye reservoir with $33 \%$ of Cladocera, $23 \%$ of Copepoda, and $44 \%$ of Rotifera. Mesotrophic Argazinskoye and eutrophic Yuzhnouralskoye reservoirs are marked by the smallest number of species (23) with 43.5-34.8\% of Cladocera, $26.1 \%$ of Copepoda and $30.4 \%$ $39.1 \%$ of Rotifera. 
Table 1 Zooplankton species biomass $\left(\mathrm{mg} \cdot \mathrm{m}^{-3}\right)$

\begin{tabular}{|c|c|c|c|c|c|c|c|}
\hline \multirow[t]{2}{*}{ Species } & & \multicolumn{6}{|c|}{ Reservoirs $^{\mathrm{a}}$} \\
\hline & & 1 & 2 & 3 & 4 & 5 & 6 \\
\hline \multicolumn{8}{|c|}{ order Cladocera, class Crustacea } \\
\hline Bosmina longirostris (O. F. Müller, 1776) & B.l & 1.9 & 9.2 & 2.0 & 16.1 & 2.0 & 7.9 \\
\hline B. kessleri (Muller, 1785) & B. $k$ & 18.9 & 0 & 32.7 & 2.0 & 51.8 & 1.2 \\
\hline Bythotrephes longimanus (Leydig, 1860) & B.lo & 49.9 & 5.0 & 7.9 & 42.9 & 1.5 & 0 \\
\hline Ceriodaphnia quadrangula (O. F. Müller, 1785) & C. $q$ & 2.3 & 16.9 & 2.5 & 11.6 & 1.5 & 14.9 \\
\hline Daphnia cucullata (Sars, 1862) & D.c & 264.4 & 2450.9 & 76.4 & 2745.1 & 6.9 & 764.3 \\
\hline D. longispina (O. F. Muller, 1776) & D.l & 4.4 & 93.4 & 24.7 & 33.8 & 0 & 167.2 \\
\hline D. pulex (Leydig, 1860) & D.p & 135.9 & 12.1 & 17.9 & 40.2 & 6.7 & 41.1 \\
\hline Diaphanosoma brachiurum (Levin, 1848) & D. $b$ & 43.7 & 0 & 39.1 & 3.4 & 0 & 19.1 \\
\hline Leptodora kindtii (Focke, 1844) & L.k & 2.9 & 2.0 & 0.3 & 6.7 & 0 & 1.9 \\
\hline Polyphemus pediculus (Linnaeus, 1761) & P.p & 50.8 & 15.6 & 37.2 & 0 & 65.9 & 7.1 \\
\hline \multicolumn{8}{|c|}{ order Copepoda, class Crustacea } \\
\hline Eudiaptomus graciloides (Lilljeborg, 1888) & E.g & 110.1 & 67.4 & 62,1 & 98.3 & 94.3 & 2.1 \\
\hline E. vulgaris (Schmeil, 1896) & E.v & 0 & 1.4 & 0 & 7.6 & 1.2 & 0 \\
\hline Cyclops vicinus (Uljanin, 1875) & C.v & 14.3 & 62.4 & 5.2 & 39.1 & 5.9 & 13.2 \\
\hline C. strenuus (Fischer, 1851) & C.s & 9.7 & 4.6 & 4.9 & 0.6 & 4.9 & 1.1 \\
\hline Mesocyclops leuckarti (Claus, 1857) & M.l & 0 & 1.8 & 0 & 13.2 & 0 & 1.3 \\
\hline Thermocyclops oithonoides (Sars,1863) & T.o & 110.4 & 1.9 & 68.4 & 1.1 & 21.3 & 0.6 \\
\hline Nauplii & - & 12.8 & 2.6 & 1.3 & 1.6 & 1.5 & 1.3 \\
\hline \multicolumn{8}{|c|}{ phylum Rotifera, class Rotatoria } \\
\hline Asplanchna priodonta (Gosse, 1850) & A. $p$ & 7.2 & 0.7 & 1.7 & 0 & 1.3 & 0 \\
\hline Bipalpus hudsoni (Imhof, 1891) & B.h & 2.3 & * & 4.5 & * & 1.8 & * \\
\hline Brachionus diversicornis (Daday, 1883) & B.d & 4.2 & 0.4 & 4.6 & 0.3 & 3.3 & * \\
\hline Diplois daviesiae Gosse, 1886 & D.d & 0 & 0 & * & 0.5 & * & 0 \\
\hline Euchlanis dilitata (Ehrenberg, 1832) & E.d & 0.9 & 0 & 0 & 0.4 & 0 & * \\
\hline Filinia longiseta (Ehrenberg, 1834) & F.l & 0 & 0 & 0.2 & 0.1 & 0 & * \\
\hline Keratella cochlearis (Gosse,1851) & K.k & * & * & * & * & * & 0 \\
\hline K. longispina (Kellicott, 1879) & K.l & 0.1 & * & 0,1 & * & * & 0 \\
\hline K. ticinensis (Callerio, 1921) & K.t & 0 & * & 0 & * & * & 0 \\
\hline K. irregularis (Lauterborn, 1898) & K.i & 1.4 & 2.1 & 2.1 & 1.4 & * & 0.9 \\
\hline K. quadrata (O.F.Muller, 1786) & K.q & 3.6 & * & 6.3 & 0.8 & 1.7 & * \\
\hline Lecane luna (O. F. Muller, 1776) & L.I & * & 0 & * & $*$ & 0 & 0 \\
\hline Notholca labis (Gosse, 1887) & N.I & 2.9 & * & 2.9 & * & 0 & 0 \\
\hline Trichocerca stylata (Gosse, 1851) & T.s & * & 0 & * & * & 0 & * \\
\hline
\end{tabular}

a Symbols for reservoirs: 1 - Shershnevskoye; 2 - Verkhne-Iremelskoye; 3 - Verkhneuralskoye; 4 - Dolgobrodskoye; 5 -

Yuzhnouralskoye; 6 - Argazinskoye

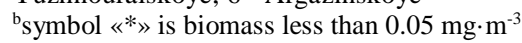

Hydrobiont species composition of the studied reservoirs is typical for the similar water bodies of the South Ural. The values of the ChekanowskySorensen index that was used to assess the similarities of dominant zooplankton species in different reservoirs differ substantially. Thus, the studied reservoirs can be grouped into three chorological complexes: I - Verkhneuralskoye and Yuzhnouralskoye; II - Argazinskoye and Dolgobrodskoye; III - Shershnevskoye and Verkhne-Iremelskoye. The index values for the reservoirs of different chorological groups were not high: from 0.31 to 0.44 (Fig. 2).

However, the similarity of zooplankton species composition for the reservoirs in identical ecological continuums was high. When calculating the amount, the average index values of 1 and 6 in comparison were 0.64 , of 1 and $2-0.80$, of 5 and 4 - 0.94 (Fig. 2). It should be noted that the index of similarity of the reservoirs different in the trophic status but having similar location is lower
(Shershnevskoye and Verkhne-Iremelskoye - 0.64) than for the reservoirs identical in the trophic status and having similar location (Argazinskoye and Dolgobrodskoye - 0.94; Verkhneuralskoye and Yuzhnouralskoye - 0.80) (Fig. 2).

Among the analyzed zooplankton groups the largest biomass of Cladocera is marked in mesotrophic reservoirs; Copepoda - in eutrophic, while zooplankton biomass of Rotifera in the reservoirs is extremely small (Fig. 3).

It is necessary to point out that, in spite of slight differences in the species composition of the studied reservoirs, zooplankton development analyzed according to the abundance and biomass approximate their trophic status. The average biomass of zooplankton in eutrophic reservoirs is significantly lower $\left(1533.5 \mathrm{mg} \cdot \mathrm{m}^{-3}\right)$ than in the reservoirs of lower trophicity $\left(6821.3 \mathrm{mg} \cdot \mathrm{m}^{-3}\right)$.

Cladocera is considered sensitive to oxygen content [25]. The obtained results show that in mesotrophic reservoirs with the oxygen-rich water 


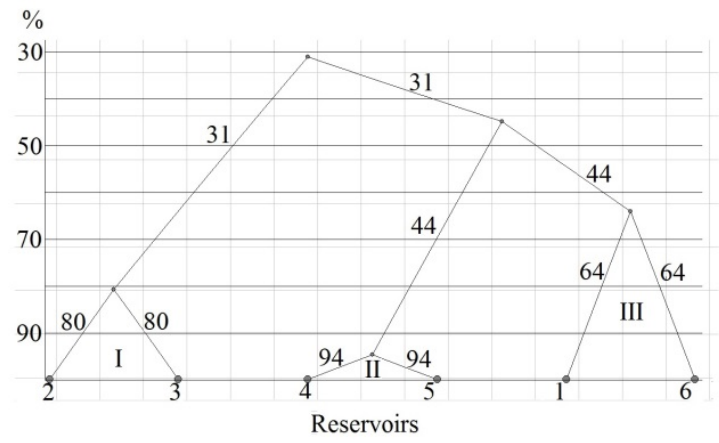

Fig.2 Similarity of main zooplankton groups in reservoirs of different trophicity according to Serenson-Chekanowsky index: 1 - 1 - Shershnevskoye, 2 - Verkhneuralskoye, 3 Yuzhnouralskoye; 4 - Argazinskoye, 5 - Dolgobrodskoye, 6 Verkhne-Iremelskoye; I, II, III - chorological complexes.

column, Cladocera biomass is much higher than in eutrophic (Fig. 4). The difference is particularly evident for $D$. cucullata biomass (Fig. 4) proving that this species is a good indicator of the reservoir's trophicity.

The situation is essentially different for eutrophic reservoirs where the amount of Cladocera is reduced to 30.9 \% (Fig. 4). Unlike Cladocera, Rotifera is not a dominant zooplankton group in epilimnion in middle summer [25]. But it is identified as predominant in eutrophic reservoirs (30.9\%) compared to mesotrophic (3.05 \%) (Fig. 4). This could be explained by anthropogenic pollution only. The situation is essentially different for eutrophic reservoirs where the amount of Cladocera is reduced to $30.9 \%$ (Fig. 4). Unlike Cladocera, Rotifera is not a dominant zooplankton group in epilimnion in middle summer [25]. But it is identified as predominant in eutrophic reservoirs (30.9 \%) compared to mesotrophic (3.05 \%) (Fig. 4). This could be explained by anthropogenic pollution only.

In mesotrophic reservoirs, the quantity of Copepoda in the total amount of zooplankton accounts for $13.7 \%$, in eutrophic - $38.06 \%$ (Fig. 4). Eudiaptomus graciloide occurs irrespective of the trophicity. The species is characterized by a wide range of tolerance. Its biomass is indifferent to the trophicity, so it can't be used as a bioindicator. Cyclops vicinus is a good indicator, on the contrary. Figure 3 shows its high sensitivity to pollution

It is essential that regardless of the trophic status of the reservoir, the same components comprise the basis of the copepod complex: T. oithonoides, C. vicinus, E. graciloides, copepodites of cyclopids of younger stages, as well as naupliuses. Apparently, they are not much sensitive to anthropogenic pollution.

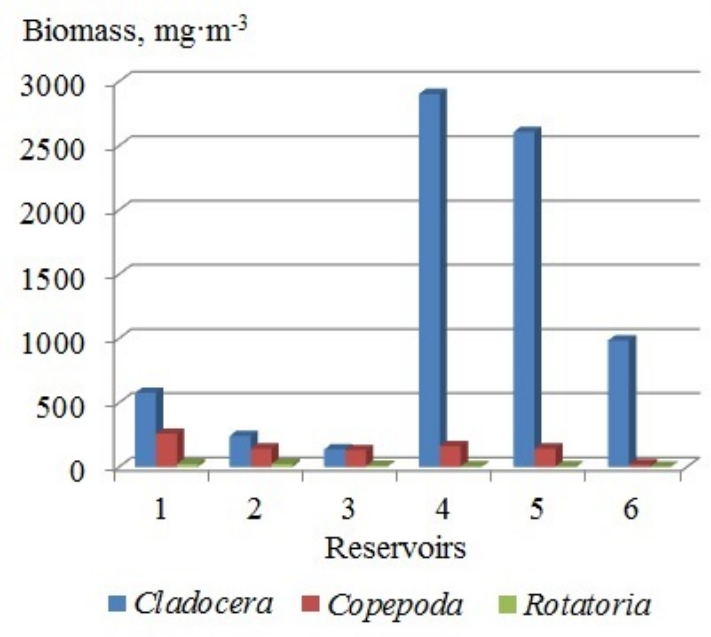

Fig.3 Biomass of zooplankton groups in reservoirs of different trophicity: 1 - Shershnevskoye, 2 - Verkhneuralskoye, 3 Yuzhnouralskoye (eutrophic reservoirs), 4 - Argazinskoye, 5 - Dolgobrodskoye, 6 - Verkhne-Iremelskoye (mesotrophic reservoirs)

\section{CONCLUSIONS}

The analysis of the numerous data allows making a conclusion about the chorological structure of zooplankton in the studied reservoirs.

Among the factors responsible for the differences in the structure are the location, the nature of the coastal line, the depth and the trophic status of the reservoir.

The study of the species composition and the biomass of zooplankton proved its heterogeneous nature. Six of the most abundant taxons are the components of the dominant complex (D. cucullata, D. pulex, D. longispina, Eudiaptomus graciloides, Thermocyclops oithonoides, Cyclops vicinus).

Only $D$. cucullata of them is a member of the dominant complex in most of the studied periods and occurs as a dominant in five reservoirs. The research shows that in eutrophic reservoirs the total biomass of the representatives of the analyzed zooplankton groups is two times less than in mesotrophic reservoirs. The biomass percentages of the dominant Cladocera, Copepoda and Rotifera groups in eutrophic reservoirs are approximately the same.

Cladocera group is significantly dominant in mesotrophic reservoirs (2.5 times more). The biomass of the Rotifera group is 10 times greater in eutrophic reservoirs than in mesotrophic ones. These are the signs indicating some degradation of biocenoses. Increasing anthropogenic load seems to have influenced the decrease in both the composition and the chorological structure of zooplankton communities in the reservoirs. 


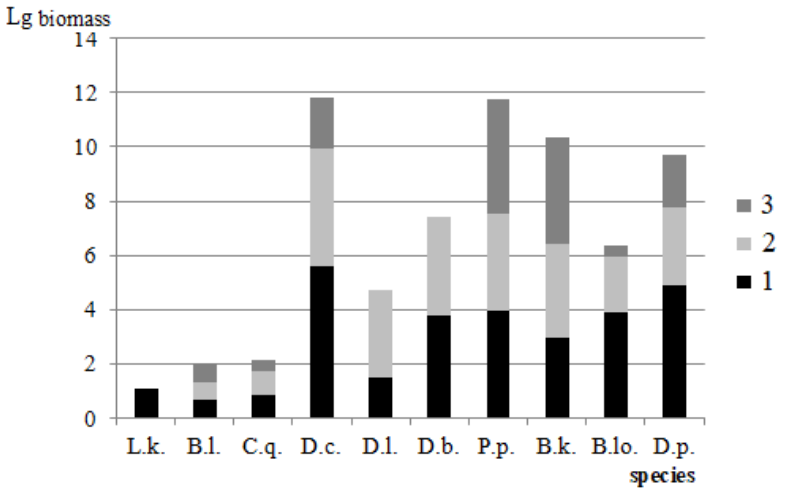

a)

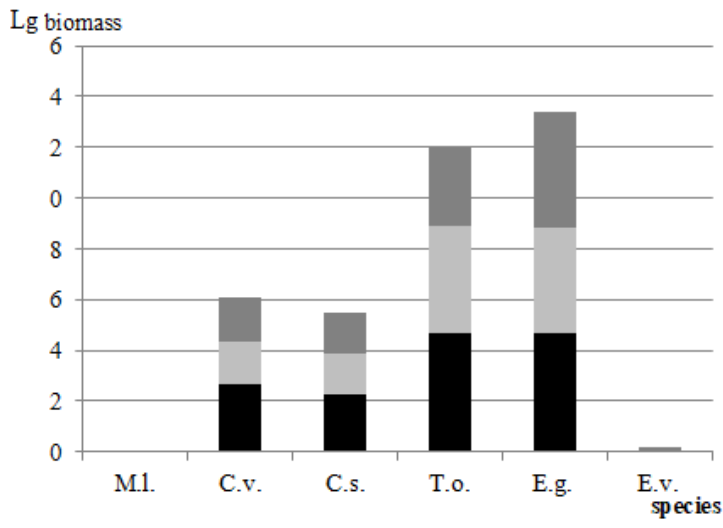

c)

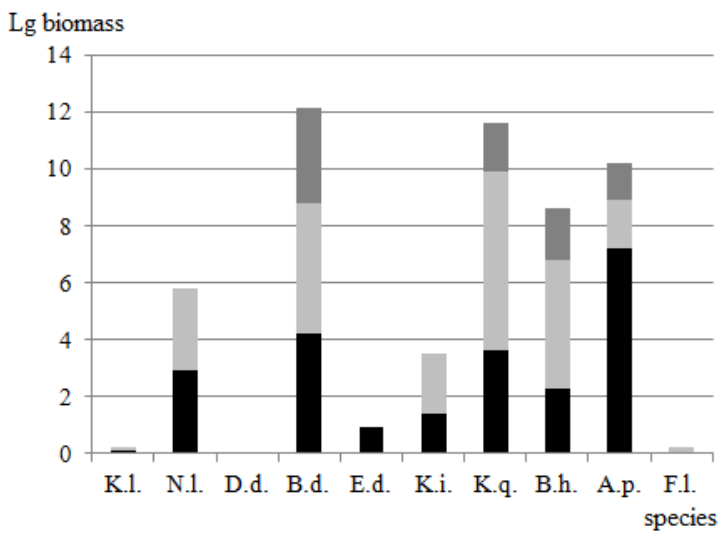

e)

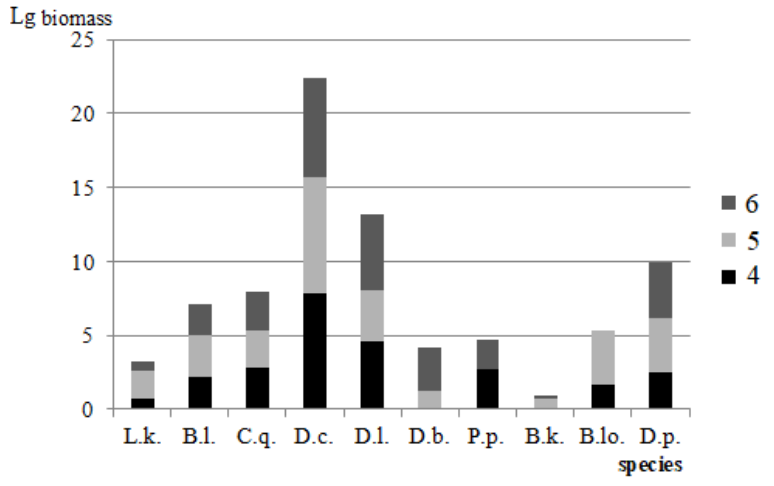

b)

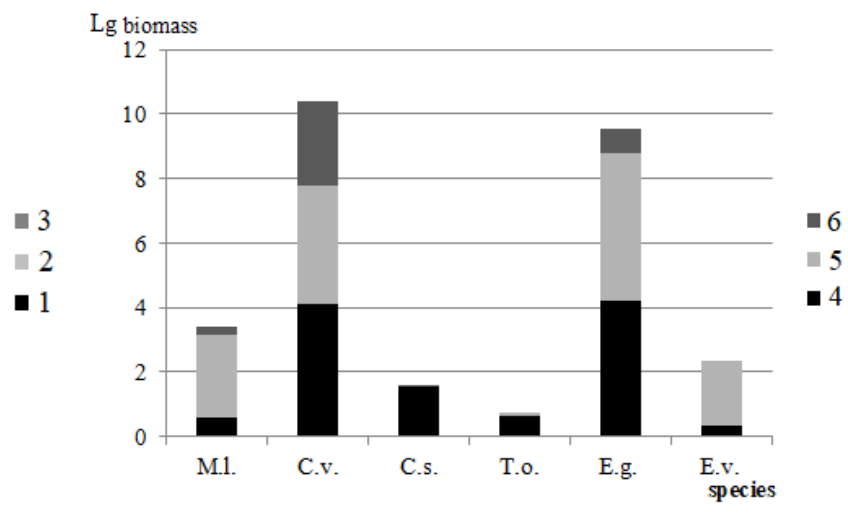

d)

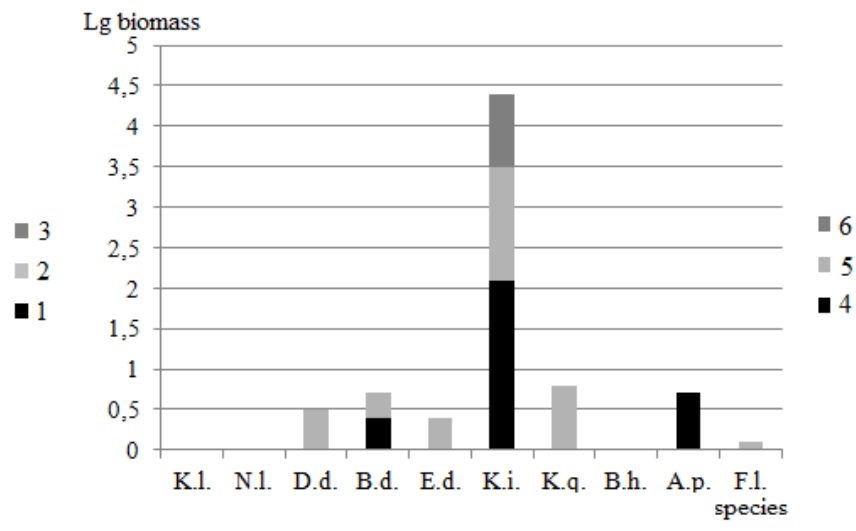

f)

Fig.4. The ratio of the logarithm of zooplankton biomass in reservoirs of different trophicity: eutrophic reservoirs (a, c, e) and mesotrophic reservoirs (b, d, f); 1 - Shershnevskoye, 2 - Verkhneuralskoye, 3 - Yuzhnouralskoye; 4 - Argazinskoye, 5 - Dolgobrodskoye, 6 Verkhne-Iremelskoye

\section{REFERENCES}

[1] Rossolimo L.L., Change in limnetic systems under the influence of anthropogenic factors, Nauka, 1977, p. 165 (In Russian)

[2] Datsenko Y.S., Eutrophication of reservoirs. Hydrological and hydrochemical aspects, GEOS2007, p. 252 (In Russian).
[3] Bengraïne K. and Marhaba T.F., Using principal component analysis to monitor spatial and temporal changes in water quality, Journal of Hazardous Materials, Vol. 100, Issue 1-3, 2003, pp. 179-195.

[4] Jekatierynczuk-Rudczyk E., Zieliński P., Grabowska M., Ejsmont-Karabin J., Karpowicz M. and Więcko A. The trophic 
status of Suwałki Landscape Park lakes based on selected parameters (NE Poland), Environmental Monitoring and Assessment, Vol. 186, Issue 8, 2014, pp. 5101-5121.

[5] Pashkova O.I., Zooplankton of the pelagic zone of the Kanevskoye reservoir and features of its spatial and temporal distribution, Hydrobiological Journal, Vol. 43, Issue 1, 2007, pp. 3-23 (In Russian).

[6] Lazareva V.I. and Smirnova S.M., Dominant systems of crustaceans and rotifers hypertrophic in Lake Nero (Yaroslavl region), Inland Water Biology, Vol. 1, 2007, pp 61-72 (In Russian).

[7] Krupa E.G., Structural indicators of zooplankton of Shardarinsky reservoir and their use in the assessment of water quality, Water Resources, Vol. 34, Issue 6, 2007, pp. 750-756 (In Russian).

[8] Ejsmont-Karabin J. and, Karabin A., The suitability of zooplankton as lake ecosystem indicators: Crustacean trophic state index, Polish Journal of Ecology, Vol. 61, Issue 3, 2013, pp. 561-573.

[9] Mashkova I.V., Kostriykova A.M., Trofimenko V.V. and Slavnaya A.I. Study of the zooplankton community as an indicator of the trophic status of reservoirs of the Chelyabinsk Region, Russia, IOP Conference Series: Earth and Environmental Science, Vol. 344, Issue 1, 2019.

[10] Mashkova I.V., Krupnova T.G. and Kostryukova A.M., Zooplankton assemblages in lake Ilmenskoe (Ilmensky reserve, Russia): spatial patterns and environmental control, International Multidisciplinary Scientific GeoConference Surveying Geology and Mining Ecology Management, SGEM, Vol. 1, Issue 3, 2015, pp. 787-794.

[11] Moss B., Stephen D., Alvarez C., Becares E., Van De Bund W., Collings S.E., Van Donk E. and Wilson D., The determination of ecological status in shallow lakes - A tested system (ECOFRAME) for implementation of the European Water Framework Directive, Aquatic Conservation: Marine and Freshwater Ecosystems, Vol. 13, Issue 6, 2003, pp. 507549.

[12] Kassikhina N.M., Zooplankton lakes with different salinities, Fisheries of reservoirs in the southern zone of Western Siberia, 1969, pp. 130-138.

[13] Pomerantseva D.P., Seasonal dynamics of zooplankton, Fisheries of Lake Ubinsky and the way of its development, 1973, pp. 27-33.

[14]Krupnova T.G., Mashkova I.V., Kostryukova A.M. and Uchaev D.A. Environmental and biological controls on elemental ratios in shells and muscles of freshwater gastropod contectiana listeri of South Ural, International Multidisciplinary Scientific GeoConference Surveying Geology and Mining Ecology Management, SGEM, Vol. 1, Issue 3, 2015, pp. 261-268.

[15] Kostryukova A.M., Mashkova I.V., Trofimenko V.V. and Vasilieva E.I., Taxonomic structure of phytoplankton in Shershnevskoe Reservoir (Chelyabinsk, Russia), an artificial lake, IOP Conference Series: Earth and Environmental Science (EES), Vol. 351, 2019, 012001.

[16] Jurczak T., Wojtal-Frankiewicz A., Frankiewicz P., Kaczkowski Z., Oleksińska Z., Bednarek A. and Zalewski M., Comprehensive approach to restoring urban recreational reservoirs. Part 2 - Use of zooplankton as indicators for the ecological quality assessment, Science of the Total Environment, Vol. 653, Issue 25, 2019, pp. 1623-1640.

[17]Azevêdo D.J.S., Barbosa J.E.L., Gomes W.I.A., Porto D.E., Marques J.C. and Molozzi J., Diversity measures in macroinvertebrate and zooplankton communities related to the trophic status of subtropical reservoirs: Contradictory or complementary responses?, Ecological Indicators, Vol. 50, 2015, pp. 135-149.

[18]Bij De Vaate A. and Pavluk T.I., Practicability of the Index of Trophic Completeness for running waters, Hydrobiologia, Vol. 519, Issue 1-3, 2004, pp. 49-60.

[19] Adams S.M., Giesy J.P., Tremblay L.A. and Eason C.T., The use of biomarkers in ecological risk assessment: Recommendations from the Christchurch conference on biomarkers in ecotoxicology, Biomarkers, Vol. 6, Issue 1, 2001, pp. 1-6.

[20]Bady P., Dolédec S., Fesl C., Gayraud S., Bacchi M. and Schöll F., Use of invertebrate traits for the biomonitoring of European large rivers: The effects of sampling effort on genus richness and functional diversity, Freshwater Biology, Vol. 50, Isue 1, 2005, pp. 159-173.

[21]Bengraïne K. and Marhaba T.F., Using principal component analysis to monitor spatial and temporal changes in water quality, Journal of Hazardous Materials, Vol. 100, Issue 1-3, 2003, pp. 179-195.

[22] Montagud D., Soria J.M., Soria-Perpiñà X., Alfonso T. and Vicente E., A comparative study of four indexes based on zooplankton as trophic state indicators in reservoirs, Limnetica, Vol. 38, Issue 1, 2019, pp.291-302.

[23] Pociecha A., Bielańska-Grajner I., Kuciel H. and Wojtal A.Z., Is zooplankton an indicator 
of the water trophic level in dam reservoirs?, Oceanological and Hydrobiological Studies, Vol. 47, Issue 3, 2018, pp. 288-295.

[24] http://www.protown.ru/russia/obl/articles/artic les_1524.html federal portal

[25]Rechkalov V.V. and Golubok O.V., Vertical distribution of zooplankton thermally stratified lakes of the Chelyabinsk region, Bulletin of Chelyabinsk State University, Vol. 5, Issue 220, 2011, pp. 110-124.

[26]http://www.xn--74-6kca2cwbo.xn-p1ai/nature/lakes/dolgoborskoe_vodohranilish che/ tourist office of the Chelyabinsk region

[27]Shitikov V.K., Rosenberg G.S. and Zinchenko T.D., Quantitative hydroecology: methods of system identification, IEVB RAS, 2003, pp. 1-463 (In Russian).

[28]Kutikova L.A. and Starobogatov Y.I.,. Key to freshwater invertebrates of the European part of the USSR, Gidrometeoizdat, 1977, pp. 1511 (In Russian).

[29] Tsalolihin S.Y., Key to freshwater invertebrates of Russia and adjacent territories, Sankt-Peterburg by Zoologicheskiǐ in-t RAN, 1994, (In Russian).

[30]Nogrady T., Pourrio R. and Segers H., Rotifera. Part 3. The Notommatidae and Scaridiidae. Guides to the identification of the microinvertebrates of the continental waters of the world, Vol. 8., Dumont H. and Nogrady T., Eds., SPB Academic Publishing, 1995, pp. 1248.

[31] Nogrady T. and Segers H., Rotifera. Part 6: Asplanchnidae, Gastropodidae, Linfiidae, Microcodidae, Synchaetidae, Trochosphaeridae and Filinia Guides to the identification of the microinvertebrates of the continental waters of the world, Vol. 18, Dumont H. and Nogrady T., Eds., SPB Academic Publishing, 2002, pp. 1-264.

[32]Kutikova L.A., Rotifer fauna of the USSR, subclass rotatoria, Zoologicheskiy Inst. Akademii Nauk SSSR, 1970, pp. 1-744 (In Russian).

[33]Benzie John A.H., Cladocera: The Genus Daphnia (including Daphniopsis)
(Anomopoda: Daphniidae). Guides to the identification of the microinvertebrates of the continental waters of the world, Vol. 21, Kenobi Productions, Ghent \& Backhuys Publishers, 2005, pp. 1-376.

[34]Kotov A.A. and Štifter P., Cladocera: family Ilyocryptidae (Branchiopoda: Cladocera: Anomopoda). Guides to the identification of the microivertebrates of the continental waters of the world, Vol. 22, Kenobi Productions, Ghent \& Backhuys Publishers, 2006, pp. 1172.

[35] Catalogue of Life: 2011 Annual Checklist http://www.catalogueoflife.org/annualchecklist/2011

[36] Abakumov V.A.,. Manual for methods of hydrobiological analysis of surface water and sediment, Gidrometeoizdat, 1983, pp. 1-236 (In Russian).

[37]Abakumov V.A., Manual for biological monitoring of freshwater ecosystems, Gidrometeoizdat, 1992, pp. 1-318 (In Russian).

[38] Standard Methods for the Examination of Water and Wastewater. Cited 44206 times, American Public Health Association, 1998.

[39] Caramujo M.-J. and Boavida M.-J., The crustacean communities of River Tagus reservoirs. Zooplankton structure as reservoir trophic state indicator, Limnetica, Vol. 18, Issue 1, 2000, pp. 37-56.

[40]Carlson R.E., A trophic state index for lakes, Limnology and Oceanography, Vol. 22, Issue 2, 1977, pp. 361-369.

[41] Mashkova I.V., Krupnova T.G., Kostryukova A.M. and Artyukov E.V., Determination of quality of water of a Shershnevskoe reservoir International Multidisciplinary Scientific GeoConference Surveying Geology and Mining Ecology Management, SGEM, Vol. 17, Issue 31, 2017, pp. 191-198.

Copyright (C) Int. J. of GEOMATE. All rights reserved, including the making of copies unless permission is obtained from the copyright proprietors. 